\title{
Artificial intelligence, communication, and democracy in Latin America: a review of the cases of Colombia, Ecuador, and Mexico
}

\author{
Daniel Barredo-Ibáñez; Daniel-Javier De-la-Garza-Montemayor; Ángel Torres- \\ Toukoumidis; Paulo-Carlos López-López
}

Nota: Este artículo se puede leer en español en:

http://www.profesionaldelainformacion.com/contenidos/2021/nov/barredo-de-la-garza-torres-lopez_es.pdf

How to cite this article:

Barredo-Ibáñez, Daniel; De-la-Garza-Montemayor, Daniel-Javier; Torres-Toukoumidis, Ángel; López-López, Paulo-Carlos (2021). "Artificial intelligence, communication, and democracy in Latin America: a review of the cases of Colombia, Ecuador, and Mexico". Profesional de la información, v. 30, n. 6, e300616.

https://doi.org/10.3145/epi.2021.nov.16

Manuscript received on $9^{\text {th }}$ May 2021 Accepted on $19^{\text {th }}$ July 2021

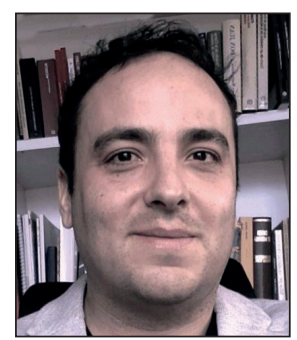

Daniel Barredo-Ibáñez

https://orcid.org/0000-0002-2259-0756

Universidad del Rosario

Escuela de Ciencias Humanas

Bogotá, Colombia

Fudan University

Shanghai, China

daniel.barredo@urosario.edu.co

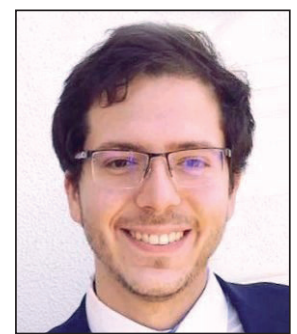

Ángel Torres-Toukoumidis

https://orcid.org/0000-0002-7727-3985

Universidad Politécnica Salesiana

Calle Vieja $12-30$ y Elia Liut

Cuenca, Ecuador

atorrest@ups.edu.ec

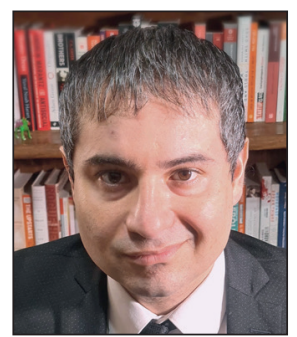

Daniel-Javier De-la-Garza-

Montemayor

https://orcid.org/0000-0001-6962-9059

Universidad de Monterrey

66238 San Pedro Garza García (Nuevo

León), Mexico

daniel.delagarza@udem.edu

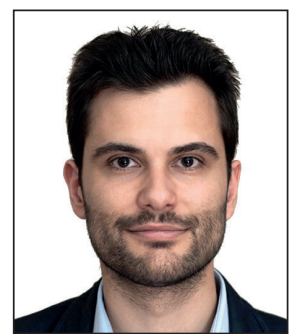

Paulo-Carlos López-López $ه$ https://orcid.org/0000-0002-8101-7976

Universidade de Santiago de Compostela Praza do Obradoiro

15705 Santiago de Compostela

(A Coruña), Spain

paulocarlos.lopez@usc.es

\section{Abstract}

The concept of algorithmic political communication has arisen through the joint development of propaganda and communication theories, as well as the findings of computer science. This is a field that generates results that amplify and extend to political communication, such as microsegmentation or automated diffusion of content; likewise, it produces some adverse effects that hinder citizen participation in the cybersphere. This paper presents a review of works published in three Latin American countries (Colombia, Ecuador, and Mexico) with artificial intelligence, communication, and democracy as their constituent elements. The data come from a total of 206 documents, including reports from supranational organisms and associations, and publications in scientific journals indexed in databases such as Google Scholar and Scopus between 2011 and 2021. The selection criterion is based on the total or partial appearance of certain keywords, plus filters by relevance and impact factors. This systematic review is structured based along four axes that explain democracy according to Landman et al. (2009): electoral participation, participation of civil society, media integrity, and impartial administration. The main conclusions indicate that many of the practices in the studied countries are still at an incipient or experimental stage, with algorithmic political communication being used especially during electoral campaigns. Similarly, an increasing resistance from civil society to the influence of social networks is starting to be detected.

\section{Keywords}

Artificial intelligence; Algorithmic communication; Algorithms; Democracy; Communication; Political communication; Latin America; Colombia; Ecuador; Mexico; Political participation; Elections; Electoral campaigns; Fact-checking; Sistematic review. 
Funding

The results of this paper are part of the work of the Research Group in Applied Ethics, Labor, and Social Change of the Universidad del Rosario, Colombia, the Gamelab-UPS of the Universidad Politécnica Salesiana, Ecuador, the Department of Administration of the Universidad de Monterrey, México, and the Political Research Group (GI1161) of the Universidad de Santiago de Compostela.

\section{Introduction and background}

\subsection{Automation, communication, and democracy}

For more than four decades, "automation of narration" has occurred in the political domain (Campos-Domínguez; García-Orosa, 2018, p. 770), i.e., links between systems developed for retransmission without human mediation. Indeed, one can go back further to Alan Turing's dreams of an automatic machine from the mid-1930s (Ferrara et al., 2016) to the first-order cybernetics, conceptualized by Wiener (1949) towards the end of the 1940s, which proposed the study and configuration of regulated systems, to the second-order cybernetics suggested by Von-Foerster (1991) to go a step further to examine self-regulated phenomena and thereby develop autonomous systems that can learn on their own in a similar way to humans and, in general, to the different applications that have been introduced into the public domain during the last 50 years to automate processes that were previously carried out through human mediation (Ruvalcaba-Gómez, 2021). These features of the background of artificial intelligence have been linked to communication for the generation and dispersion of automated content (Barredo-lbáñez, 2021) in the perspective of computational propaganda (Bradshaw; Howard, 2017) or "algorithmic political communication" (Campos-Domínguez; García-Orosa, 2018, p. 771).

The relationships between communication and artificial intelligence are strongly associated with these specific antecedents of computer science but are also linked to the joint development of propaganda and communication theories throughout the twentieth century (Pizarroso-Quintero, 1999). Nevertheless, the boost to automation and its effects on democracies has social roots. The interest of organizations and institutions in the digital public sphere (as an extension of the Habermasian public sphere) has complemented videopolitics (López-López; Oñate, 2019), as there is a progressive transition in the access to audiences, who are transformed into users identified with the consumption and production of news and virtual content (Fernández-de-Arroyabe-Olaortua; Lazkano-Arrillaga; Eguskiza-Sesumaga, 2018).

Thus, from the end of the 1990s, gradual massive access to information and communication technologies has occurred (Barredo-Ibáñez, 2021) through platforms and spaces that enable collective participation, such as chats, social networks, forums, or instant messaging applications, among others. This growth in the data available to citizens, in both developed and developing countries, has also implied greater exposure to virtual information content (Weaver, 2020) and, consequently, different viewpoints. It is important to note that, regarding the elements of high-quality democracy, O'Donnell, Vargas-Cullell and Lazzetta (2004) remarked on the importance that citizens be informed though different information sources that are independent of political power. The emergence of cyberspace seemed to provide such an environment to consolidate a new communication medium beyond the control of media and government power (Castells, 2012). The participatory use of these technologies was so significant that some authors have even suggested the emergence of a new type of social state based on tools with a strategic purpose, viz. technopolitics (López-López; Oñate, 2019).

This progressive transition in the consumption and co-construction of information and opinion about matters of public interest has had a substantial impact on some recent historical events that have tested contemporary democracies (Piechota et al., 2020). Since the protests in Tunisia and Egypt that disturbed international public opinion in 2011, social media (i.e., media co-constructed through user contributions) have acted as sites that have enabled wider access to information compared with traditional media in the current information age (Ghoni, 2013). This change has become more evident since 2015, when younger citizens abandoned traditional media to receive information through digital media. Convergent media enabled a space for the consumption of information in real time, but they also became a showcase of public opinion. Over time, this transition would extend to other generations (Bañuelos, 2017). As the digital gap was progressively reduced and the number of convergent technologies (such as cell phones and electronic tablets) increased, access to virtual content was enabled and social networks became indispensable media for understanding social life (De-la-Garza-Montemayor et al., 2019; Tana; Eirola; Nylund, 2020).

According to the popular book by Castells (2012), these networks of indignation and hope were gradually colonized by organizations and institutions during the first decade of the 2000s. This transformation in consumption meant that governments in different parts of the world faced a considerable challenge resulting from the influence exercised by social networks on public opinion (Hobden, 2018). In other words, these media were progressively transformed into the bipolar space seen in 2021: on the one hand, an environment presenting content generated by users, such as videos, audios, and texts, and where personal testimonies, such as opinions about world events (Bañuelos,

The networks of indignation and hope were gradually colonized by organizations and institutions during the first decade of the 2000s 
2017; Fernández-de-Arroyabe-Olaortua; Lazkano-Arrillaga; Eguskiza-Sesumaga, 2018) or personal experiences are broadcast, but on the other hand, a battlefield for contemporary democracies, in which attempts at public opinion manipulation (Cerón-Guzmán; León-Guzmán, 2015; Bradshaw; Howard, 2017) and geostrategic positioning (Morgus et al., 2019) coexist with collective deliberation. Although social networks have become an important space for interaction, some worrying aspects have also become apparent and been the subject of recent studies. One of these is the loss of privacy by users, who often share personal information on social networks (Swigger, 2013; Yerby; Koohang; Paliszkiewicz, 2019). In other words, as stated by Cerón-Guzmán and León-Guzmán (2016), there has been an expansion of the personal footprint of individuals, leading to demands for new methods to address this enormous amount of content. A line of reflection and analysis has also emerged to compare and (self-)regulate by employing artificial intelligence to detect other artificial intelligence with spurious purposes (Ferrara et al., 2016; Cerón-Guzmán; León-Guzmán, 2016; Cumbicus-Pineda, 2017; Glowacki et al., 2018).

\subsection{Algorithmic political communication}

Algorithmic political communication thus amplifies and extends some developments that hybridize propaganda and communication, according to the controversial relationship between the theoretical and practical work developed during the twentieth century and possibly since the French Revolution of 1789. This type of communication, as described by Campos-Domínguez and García-Orosa (2018), consists of three large and interrelated processes:

- increasingly personalized opinion based on segmentation and microsegmentation;

- content generation that sometimes blurs the distinction between nonfiction and fiction; and

- the diffusion and rediffusion of these.

An example of this is the proliferation of false news or disinformation (often called fake news), which is one of the main risks facing contemporary democracies, i.e., news that is intended to confuse public opinion, as well as content generated with a lack of journalistic objectiveness (Illades, 2018; Walters, 2019). However, disinformation is a more complex phenomenon that extends beyond spurious news (Rodríguez-Pérez; Ortiz-Calderón; Esquivel-Coronado, 2021). There are also models that, as in the case of diluted promotion (Barredo-lbáñez, 2021), aim to construct information environments that dilute brand positioning and thereby achieve wider circulation and recirculation. Impact and brand recall are encouraged through promotion by staging allegedly objective information, in a liquid ecosystem that has eroded programming criteria in favor of individualized consumption (Timoteo, 2005). Disinformation or fake news (which is more aggressive, similar to propaganda in wartime) and diluted promotion (which is more informative, being linked to the concepts of brand placement or surreptitious advertising) require the establishment of systems such as social bots that are responsible for amplifying such persuasive statements (Cerón-Guzmán; León-Guzmán, 2015). Independently of the mediator mechanism, their impact is ensured by some key aspects of mass psychology. In this sense, according to Bendall and Robertson (2018), people exhibit a certain resistance to not believing news that reflects their mindset, even when false. This has contributed to a consolidation of so-called post-truth, in which hard data are relegated to the background while perceptions have a decisive influence on public opinion (Mclntyre, 2018). On the other hand, according to Kim and Dennis (2019), users tend to trust information that is close to their ideological beliefs, even when there is evidence that it may be opposed to the truth, in order to prevent the occurrence of cognitive dissonance.

We present herein a review of algorithmic political communication from works published in three Latin American countries (Colombia, Ecuador, and Mexico) regarding the study of its core elements of artificial intelligence (Al), communication, and democracy. The review of these three concepts and their relationships and effects is motivated by recent research work from both the English-language (Nemitz, 2018; Pérez-Casares, 2018; Helbing et al., 2019) and Iberoamerican (Castellanos-Claramunt, 2019; Innerarity, 2020) literature.

The interest of the present study is thus justified based on its relevance and theoretical value (Hernández-Sampieri; Fernández-Collado; Baptista-Lucio, 2010), to broaden knowledge and evidence regarding the so-called Global South, from both the social and institutional points of view (Thomas-Slayter, 2003; Rigg, 2007; Braveboy-Wagner, 2009). The documents reviewed mainly include publications in scientific journals indexed in the Google Scholar search engine and Scopus database, filtered by relevance and impact factors. Reports from supranational organisms and associations have also been found, being included based on their year of publication, reference to any of the studied countries, the data sampled, or the inclusion of longitudinal analysis.

This systematic review focuses on the four axes that explain democracy according to Landman et al. (2009):

- electoral participation;

- participation of civil society;

- media integrity; and

- impartial administration. 
The selection of these axes as elements structuring this review is supported by the International Institute for Democracy and Electoral Assistance (IDEA) and is framed around the democratic principles and values that operate as mediators, namely participation, authorization, representation, responsibility, transparency, response capacity, and solidarity (p. 14).

The selection of the three countries is justified because Colombia, Ecuador, and Mexico exhibit similar historical trajectories and cultural imaginaries, as well as a technology gap, where fewer than seven out of ten citizens (BID, 2020, p. 19) have access to the Internet, thus identifying this region as one of those with the greatest social inequality (p. 20). Various comparative studies have been conducted among these three countries in different disciplines such as communication or political science (Barredo-Ibáñez; Díaz-Cerveró, 2017; Gutiérrez-Atala et al., 2017; Rúas-Araújo; Casero-Ripollés, 2018), as well as within the Latin American framework. Based on this, the following two research questions are established:

Q1: Is it the electoral context that describes and makes sense of the studies about algorithmic political communication in Colombia, Ecuador, and Mexico?

Q2: Do the self-organization mechanisms of civil society generate a type of resistance to the influence of social networks?

\section{Methodology}

To analyze the literature published in these three Latin American countries (Colombia, Ecuador, and Mexico) regarding the relationship between artificial intelligence, communication, and democracy as constituent elements of algorithmic political communication, a descriptive scope was established for this study based on a critical review of the literature (Arnau-Sabatés; Sala-Roca, 2020). To present a detailed description of the methodological design, the steps proposed by Codina (2018) and Xiao and Watson (2019) are considered. The objective is to conduct a systematic literature review on the mentioned aspects, identifying trends and streams in the area while also detecting research gaps and opportunities (Codina, 2018). The following steps are applied:

- Criteria for including and structuring the axes. The first criterion applied to include works from any discipline is that they must address an aspect regarding the established relationships between artificial intelligence, communication, and democracy. The conceptual framework is thus defined, and a model for organizing the knowledge about the discipline determined (Hart, 2008). Therefore, works from fields as diverse as political science, studies about communication or journalism, and even some works from engineering areas were included. Only studies published in Spanish or English language were selected. As a first step, the selection of the theoretical axes that structure and interpret the work is described, together with the definition of the inclusion criteria. As stated above, four axes that define democracy are chosen according to Landman et al. (2009): electoral participation, participation of civil society, media integrity, and impartial administration.

- Identification of the universe ("search"): To identify the universe of published papers, a search was conducted between 10 February and 10 March 2021 using the following keywords (Arnau-Sabatés; Sala-Roca, 2020) in both English and Spanish:

"artificial intelligence," "communication and democracy," "artificial intelligence and communication," "artificial intelligence and democracy," and "algorithmic political communication"

The initial selection of papers was carried out based on the total or partial appearance of these keywords in either the title or the abstract, in addition to a relevance criterion based on the citation index, excluding works from the last two years. This universe was delimited using Google Scholar and Scopus, a search engine and database that, as explained by Xiao and Watson (2019), are used by "researchers of various disciplines" (p. 93). The time range established to identify these works was from 2011 to 2021 . Initially, we identified 206 documents that totally or partially included the search terms. To obtain a wider view, it is important to note that the search was extended from publications indexed in scientific journals to include reports from supranational organisms and associations, too.

- Modeling the sample. After reading the titles and abstracts of the 206 documents obtained, their relevance was discussed through the implementation of a nominal group (Guillén-Zanón, 1990) in two phases, the first aimed at excluding works by consensus and the second focused on a discussion of the discrepancies. Many works that addressed the phenomenon only partially were identified, preventing their further inclusion. A total of 98 works were thus included to understand the relationship between the three items of artificial intelligence, communication, and democracy.

- Review of quality and organization (evaluation). Having downloaded the texts of the 98 works, a total of 30 were discarded in this phase because they were not relevant or significant (source of prestige or citations), or because complete documents were not found. Following this process, 68 texts were obtained and organized according to their association with the four axes that define democracy (Landman et al., 2009) to form the final sample for analysis.

- Relationship with general literature (analysis and synthesis). A first draft was written based on the four planned axes from general literature. After this preliminary step, each author was responsible for analyzing and composing a critical synthesis of a group of assigned works. Thereafter, the main author was responsible for systematizing the contributions with successive interactions until common ground between the documents was identified. Finally, this paper was subject to at least two joint revisions by the authors based on dialog between the contributors. 
However, one should also note the following limitations of the current systematic review (Sancho, 1990; Araujo-Alonso, 2011):

(a) the high volume (overload) of information in political communication and applied technologies, also in Latin American;

(b) possible errors in the search strategy, despite the improvements applied (double searches);

(c) information bias (due to publication bias and the limitations of databases);

(d) access limitations (due to unavailability);

(e) the sense and usefulness of scientific documents (although their impact and citations may demonstrate their value, the absence of these features does not indicate the opposite);

(f) other biases of the authors.

\section{Artificial intelligence and electoral participation}

Events such as the Cambridge Analytics scandal during Donald Trump's campaign in 2016 contributed to the generation of mistrust among social network users by demonstrating that data (photographs, videos, and opinions) provided to such platforms may end up being used for purposes different from those to which users have consented. These events offer a narrative that contrasts with the libertarian vision at the beginning of the last decade (Heawood, 2018; Kaiser, 2019). For this reason, it is important to indicate that the political and social polarization that characterize most contemporary democracies are also present on social networks and, in some cases, even more acutely than in the real world. The confrontation between different political forces, the division between communities and social groups, as well as the malaise of majorities have turned these media into a true virtual battlefield (Singer; Brooking, 2018).

One should also note that democracies went into crisis just in the historical period in which these virtual tools became established. For example, during the economic crisis of 2008, electoral forces with antisystem positions arose in various Western countries (on both the right and left) and, surprisingly, started to obtain good electoral results. This simultaneous process of disenchantment is also tightly linked to technological changes (Denneen, 2018; Galston, 2018; Davies, 2019).

This institutional instability, which resulted in the victory of populist candidates that threaten to undermine some of the essential bases of Western democracy, has been partially facilitated by the diffusion of messages with radical viewpoints through social networks, which formerly did not find a place in the mass media. In other words, the agendas of radical groups can now more easily achieve greater diffusion through digital media, because of the diversity of alternatives available in cyberspace and because of the nearly identical access provided to both professional media and others (Judis, 2016; Marantz, 2019). This is in accordance with research by Yerlikaya and Toker-Aslan (2020), who point out that digital media have become a channel by which some social players with extremist ideological positions end up spreading hate messages, having an enormous impact on society.

The latter has affected electoral participation, the first premise described by Landman et al. (2009) about democracy. In this sense, electoral participation in the Al framework tends to operate through computational propaganda (Bradshaw; Howard, 2017), through which attempts to "manipulate public opinion within social media" (p. 3) are promoted. These authors, who studied the strategies and repertories of 28 countries, including Ecuador and Mexico, highlight the existence of so-called cyber-troops enabled by different areas of government, political parties, or even services outsourced by institutions or organizations to favor such manipulation. Indeed, Bradshaw and Howard (2017) found evidence of automated and human use of manipulation strategies in Ecuador as well as Mexico. In the latter, they even detected cyborgs (p. 13) which, as explained by Clark et al. (2016), are bots or automated systems that can simulate human behavior.

Fundamentally, computational propaganda seeks to generate artificial opinion streams, which Barredo-lbáñez (2021) describes as a "spiral of silence 2.0" (p. 350). In other words, this involves establishing strategies to enter user discussions to encourage the spread of positive content about the candidates or representatives they support or, conversely, negative content that smears or provides disinformation about rivals. Obviously, computational propaganda requires large investments and is thus especially activated during electoral processes. At present, major powers may intervene directly using such cyber-troops with the aim of introducing their narratives into the agenda in other countries. According to Morgus et al. (2019), Russia and China operate in the Latin American cybersphere to protect their political and commercial interests, although the Western world also includes many countries, such as the USA or Germany (Bradshaw; Howard, 2017), that also tend to interfere in the cybersphere. Indeed, those authors assure that cyber-troops have become a "global phenomenon" (p. 3).

Regarding the effect of computational propaganda in elections, we identified two diametrically opposed perspectives, according to the number of bots taking part during the period. 
In the first perspective, Cerón-Guzmán and León-Guzmán (2015) studied the presence of social bots spreading spurious content on Twitter during the 2014 presidential elections in Colombia. According to these authors, 22\% of users were classified as "spammers," being responsible for generating $15.67 \%$ of the total number of tweets analyzed (p. 122). Although this percentage of social bots seems very high, this evidence is not conclusive. Rather, it seems that these social bots intervene on particular critical topics.

From the second perspective, Fabra-Mata and Mygind (2018), when examining mentions of Norway in tweets about the Colombian peace process, found that less than $0.5 \%$ came from bots (p. 6). Similarly, when investigating messages spread on Facebook and Twitter during the 2018 presidential elections in Mexico, Glowacki et al. (2018) found more content shared from journalistic sources than from potential sources of disinformation, on both platforms. On the other hand, even though they did not specify the number of bots, Puyosa (2017) found trends on Twitter during the presidential elections in Ecuador in 2017, including the automation of electoral propaganda, promoting polarization and mistrust of democratic institutions.

Along the axis of electoral participation, close links may exist between commercial and electoral campaigns. Regarding this issue, Luque, Macías, and Casado (2021) identified the migration of commercial bots for use as electoral bots in Ecuador. In other words, bots that were previously used for spreading business strategies (including massive or diluted promotion) were transferred to electoral campaigns. No new bots were created, but they changed their objective, in this case being adapted for the 2021 presidential campaign in Ecuador. Similarly, during electoral processes, automated statements from bots are adapted to spread hate speech as well as to establish a hegemonic narrative. Likewise, Calderón (2019) demonstrates the use of artificial intelligence to adapt the messages of the electoral campaign for the Municipality of Quito in 2019, to influence voters and polarize the voting by means of social networks. In this case, it is evident that data mining, a fundamental artificial intelligence (AI) tool, has been incorporated into political campaigns in Ecuador, enabling predictable voting patterns to be obtained by molding the information sources consulted by citizens.

Moreover, bots also take part in other, complementary strategies along the axis of electoral participation through social network management. In this regard, when studying the use of Facebook during the 2018 presidential elections in Mexico, Toxtle-Tlachino and González-Macías (2020) concluded that the current Mexican president used this service to promote his ideas or public image but not for discussions with voters. This promotion was achieved through the use of bots or spreading disinformation via Twitter, Facebook, and WhatsApp, as explained by Lupu, Ramírez-Bustamante, and Zechmeister (2020), who addressed the relationship between mistrust and social media in some Latin American countries. The Mexican presidential elections in 2018 triggered a mobilization of coordinated social groups such as Christians that were decisive in the victory of López Obrador, as pointed out by Boas (2020), who focused on examining the role of this collective in some Latin American elections. Similarly, the spread of disinformation has been key in other electoral processes, such as the 2018 presidential elections in Colombia, where Chenou, Cabarcas-Velandia, and Sepúlveda-Marín (2021) observed the existence of "echo chambers" (p. 137) in WhatsApp groups related to Iván Duque. Through the repetition of similar and distorted concepts, the prestige of the candidate Duque was strengthened among his followers while also smearing other candidates. Baker, Ames, and Rennó (2020) analyzed the influence of social media in voting trends in Latin America: Latin American users, since they are associated with various collectives (family, and social or labor groups), are permanently subject to the preferences shared by such collectives.

In the reviewed works about electoral participation, we observed one perspective that originates from the field of exact sciences, i.e., the connection between electoral participation and a more technical, more instrumental notion. In this regard, Toapanta-Toapanta et al. (2019) remark on the robustness of digital counting systems to prevent manipulation and extortion in Ecuador. On the other hand, Cerón-Guzmán and León-Guzmán (2016) proposed an automatic learning model to predict opinions related to presidential candidates in Colombia. For this purpose, they conducted a study of the 2014 presidential elections by examining more than 600,000 tweets selected using various keywords or hashtags. Similarly, Cumbicus-Pineda (2017) designed an automatic categorization of tweets based on supervised learning algorithms aimed at the 2017 presidential elections in Ecuador, confirming the suitability of support vector machines to identify political trends in messages spread through this social network.

\section{Artificial intelligence and participation of civil society}

The second premise considered by Landman et al. (2009) related to democracy is the participation of civil society, in this case corresponding to the technopolitical aspect of societies (López-López; Oñate, 2019). It is hard to separate measures to address the spread of disinformation through social networks from government control. Various research works have considered the need for civil society or academic institutions, through their own digital media, to become key elements that can contribute to the generation of initiatives to recognize those objective media or platforms, as well as warning society about media that contribute to disinformation (Chen, 2018; Cha; Gao; Li, 2020).

As indicated in the "Introduction," citizens now use tools enabled by information and communication technologies. In the case of Mexico, De-la-Garza Montemayor et al.(2019) examine the concept of citizen participation by studying 
university students in Mexico compared with Peru, observing a progressive activation of users in the cybersphere. Technopolitics was driven by the \#YoSoy132 movement, which enabled generalized participation that blurred the reach of the large TV stations in the country, Televisa and TV Azteca. On the other hand, Muthiah et al. (2016) conducted a review of riots over social conditions in ten countries, including Ecuador, to analyze the particular advantages of social networks compared with traditional media based on the implementation of the algorithmic infrastructure in the Basis Rosette linguistic platform, to address the mentions and dissemination of the national protests. Besides, Domínguez-Ávila, Vásquez-Von-Schoettler, and Rezende-da-Silva (2019) define the influence of artificial intelligence in virtual spaces, enabling access to and production of metadata and the development of critical thinking, thus leading to a new digital sovereignty for citizens.

In addition, we found numerous documents focused on examinations of the influence of disinformation in the participative processes of citizens. When reflecting on the relationships between communication media and politics regarding the 2016 Peace Agreement, Roa-Roa (2019) points out that the distinctive aspects of social networks (such as spontaneity or abundance of information flow), which are very useful for electoral processes, collide head-on with the rational explanation of the agreement. Indeed, it was the emotionality of social networks that blurred the need for an eminently rational election process, in which the decision was between a proposal for ending the armed conflict and hence transforming the country (the peace agreement), and a demagogy associated with hate (p. 206), which was ultimately successful. Similarly, Rodríguez-Pérez, Ortiz-Calderón, and Esquivel-Coronado (2021), who analyzed the impact of the dissemination of fake content regarding the 2019 national strike, confirmed that much of the spurious content analyzed was oriented toward institutional players, thus contributing to the establishment of a polarization between "them and us" (p. 148).

The axis describing the participation of civil society highlights the use of these technologies by users who have a high profile due to their entrepreneurial, sports, or other activities, apart from politics. Along this line, Gater (2020) argues that populist figures are often successful in disseminating false information through these media, which may be related to the need of this political stream to offer a redemptive narrative to voters based more on collective aspirations than concrete events. Virtual media, like traditional media in the past, contribute to the generation of perceptions among the population, which in many cases may be far from reality (Eichengreen, 2018). A similar result was obtained in the study by Guerrero-Solé et al. (2020), who identified that populists have found social networks to be a suitable platform for spreading messages that are simplistic and lack arguments but that may have a significant electoral impact among voters who are disenchanted with the system. In contrast with the optimism at the beginning of the last decade, social networks are little used as a space for introspection or the discussion of transcendent subjects, becoming thus a space for messages that have a notable impact in some cases but that are rarely transcendent (De-la-Garza-Montemayor; Yllán-Ramírez, 2020).

\section{Artificial intelligence, media integrity, and impartial administration}

The third axis associated with the conceptualization of democracy by Landman et al. (2009) is media integrity. Simpson (2016) points out that these virtual media have incorporated various aspects of the agenda of extreme right-wing parties into the public agenda of some European countries. This occurs in both the parliament and regional or national governments. An emblematic case was the referendum in the United Kingdom about exiting from or remaining in the European Union. The campaign team that promoted Brexit (mainly constituted by Eurosceptics, nationalists, and extremists) disseminated messages through social networks that promoted prejudices against immigrants, as well as information that was openly false. One could argue that this new political communication tool had an important impact on the referendum result, which was considered to be surprising (Clarke; Newman, 2017; Hall; Tinati; Jennings, 2019; Mancosu; Bobba 2019). Another emblematic example of this is the case of Poland, a country where the Law and Justice party has obtained a strong foothold in recent years, through a process that has reversed some of the checks and balances pertaining to a democracy with institutional equilibria. In this country, virtual social networks have become the main platform for the spread of messages by both the extreme right wing that governs as well as pressure from the streets to achieve greater radicalization (Lipiński; Stępińska, 2018; Applebaum, 2020). Another symbolic case is the repeated use of these digital platforms by Donald Trump, former president of the USA, to refer to racial minorities and foreigners in a negative way, as both a candidate and governor. Similarly, in Brazil, WhatsApp became a medium through which extremist messages from Jair Messias Bolsonaro, candidate for the presidency of Brazil, were disseminated (Canavilhas; Colussi; Moura, 2019; Bonow-Soares, 2020).

With respect to media integrity, we found that the analyzed documents can be described along three axes, referring to freedom of expression, monitorization, and fact-checkers. Regarding the first topic, Albán-Cabezas (2019) considers that the digital ecosystem is increasingly being flooded with emulators based on intelligent machines that systematize the dissemination of false news, but he recommends that the Ecuadorian state should not implement regulations and sanctions against this scourge, in order to safeguard freedom of expression, rather adding public policies that will boost digital literacy and the introduction of an authorized, official seal of quality to emit news. Regarding the

In the 2018 presidential elections in Colombia, were observed the existence of "echo chambers" in WhatsApp groups related to Iván Duque 
second axis, Torres, Vaquerizo, and Vaca (2015) point out that machine learning techniques such as mixture models, hierarchical clustering, and variable models, including Dirichlet allocation, may target the collection of public opinion patterns on social networks via communication media, as is done herein, focusing on two Ecuadorian newspapers. This will make it easier to identify relevant topics and characterize the audience and speeches by political leaders. However, other perspectives arise along the same axis that consider media integrity beyond its association with communication media. Regarding this issue, Montenegro-López (2020) presented a theoretical model to exploit data from the CoronApp application, proposed by the Colombian government to provide information about the possible symptoms of Covid-19. According to the author, monitoring the data obtained from this application may be very useful regarding its use in regions where diagnosis of the disease is made difficult by economic issues. Regarding media integrity, it has been confirmed that artificial intelligence can play a proactive role in news verification platforms. Rodríguez-Pérez (2020) reports how platforms such as Ecuador Chequea (Ecuador), or Colombiacheck and La Silla Vacía (Colombia) are fed by machine learning to collect official information and detect false news, thus speeding up the verification process.

Regarding the final premise, related to Al and democracy, and impartial administration, the scientific literature is sparse, as already mentioned by Landman et al. (2009) and Ruvalcaba-Gómez (2021), despite the wide use of this type of technology by public administrations. A report published by the BID (2020) described the panorama of advances in AI used by various public administrations in Latin America and the Caribbean. Although the results therein suggest that $A \mathrm{I}$ may help to reduce the gaps in this rather unequal region (p. 20), its use remains irregular, having been implemented by the government of Colombia but not in Ecuador, whereas its introduction in Mexico is ongoing. Since 2019, Colombia has had a National Policy for Digital Transformation and Al, with the aim of strengthening the use of this technology in both the public and private sectors. Similarly, the Colombian government granted scholarships to 25,000 public officials to train them on these topics (p. 70). Although the public administration in Ecuador still lacks an Al strategy (p. 84), Gómez-Mont et al. (2020) contextualize the general advances of this technology in this country, reporting that, although the government has driven a digitalization strategy with projects such as Ecuador Conectado, Ecuador Eficiente y Ciberseguro, and Ecuador Innovador y Competitivo, and despite the formal dialog between academy, industry, and government to promote the use of Al, no official strategy has developed a plan with priorities aimed at academic and scientific development of this line of research. The implementation thus remains at an initial stage, mainly being limited to the financial (Barrientos-Avendaño et al., 2020), medical (Álvarez-Vega; Quirós-Mora; Cortés-Badilla, 2020), and educational (Méndez-Zapata et al., 2015; Tapia et al., 2021) sectors.

In 2018, a multisector corporation called IA2030Mx was created in Mexico (BID, 2020, p. 90) to promote the expansion of the Al ecosystem based on links between the public and private sectors. However, this project remains at a development stage and is far from reaching fruition. In this sense, Ruvalcaba-Gómez (2021) conducted a survey of leaders of information and communication technology departments from 218 Mexican municipalities with more than 100,000 inhabitants. That study found that the incorporation of Al into public administrations in Mexico was still incipient. However, the cited author also proposed a gradual replacement of "repetitive and systematic tasks" (p. 130), which may require decision-making associated with creativity and complexity as the main attributes of future governments.

Another critical aspect of Al is its implementation in security and surveillance. In this regard, some studies have directly considered the fate of democratic processes from the point of view of engineering fields. Alcivar, Sanzogni, and Houghton (2016) diagnosed Al strategies oriented toward successful adoption of information systems in Ecuadorian public organizations, compiling and evaluating cases from Latin America. Additionally, Alcivar, Houghton, and Sanzogni (2017) presented a predictive model and applied it to government information systems to determine the attitude and behavior regarding its use in public organizations in Ecuador. In other words, an attempt was made to implement computerized technology to recognize the use of government digital services through institutional interfaces. On the other hand, Patiño (2021) explored the incorporation of Al into the security forces of Mexico, proposing a strategy that is still under development, called "predictive policing" (p. 211), which would help to prevent potential crimes. This strategy uses Al to analyze large volumes of data, with the purpose of anticipating possible crimes. Similarly, Proaño-Salazar (2021) proposed algorithms for monitoring public purchase processes in Ecuador. Using this tool based on Al, it is possible to detect any type of malpractice associated with the management of public resources.

\section{Conclusions}

The relationships between $\mathrm{Al}$, communication, and democracy are studied as core elements of algorithmic political communication according to the axes proposed by Landman et al. (2009) to conceptualize democracy, using Colombia, Ecuador, and Mexico as example countries. As reported by Campos-Domínguez and García-Orosa (2018), many such practices are still in an "incipient or experimental" phase (p. 775). At least, the analyzed literature describes the use of algorithmic political communication in particular during electoral campaigns, which involves a greater investment of resources (Q1), and during such periods, a complementary use of strategic management is revealed. Compared with other countries, a key difference that should be addressed in future studies is that, even though large powers tend to 
operate in a transnational manner (Morgus et al., 2019), affecting or attempting to affect democracies in other contexts, the impact of the cyber-troops of Ecuador or Mexico (Bradshaw; Howard, 2017) or the bots detected in Colombia (Cerón-Guzmán; León-Guzmán, 2015), or other more or less automated strategies seen in that country (Chenou; Cabarcas-Velandia; Sepúlveda-Marín, 2021), in other global contexts remains to be seen. This represents a gap in the extant literature, according to the review above.

Based on the current review, the Covid-19 pandemic has accelerated the process of digital transformation in these three countries in various areas: educational institutions, interpersonal communication, and communication media (Mladenova; Kalmukov; Valova, 2020). This applies in particular to democracies that, in recent decades, have been reconfiguring their relationships with audiences from videopolitics to cyberpolitics (López-López; Oñate, 2019), even in countries affected by a technological gap and inequality $(B I D, 2020)$, such as those studied herein.

The transition to cyberpolitics depends on the credibility of the content disseminated (Cerón-Guzmán; León-Guzmán, 2015), since its impact in contemporary democracies is such that, through constant repetition and dissemination on multiple platforms, the possibilities of reaching a social consensus is eroded (Rodríguez-Pérez; Ortiz-Calderón; Esquivel-Coronado, 2021). This applies more so to fragile societies such as those in Latin American, where social influence is often predetermined by core relations, e.g., within the family or group of friends (Baker; Ames; Rennó, 2020). The disinformation of false news may end up harming democracies, especially those with weak institutions (Sierra-Caballero; Sola-Morales, 2020), such as those of Colombia, Ecuador, and Mexico. It is therefore necessary to advance research in the face of big data to enable the identification of the marks of collective participation (Cerón-Guzmán; León-Guzmán, 2016).

According to this literature review, we coincide with Ruvalcaba-Gómez (2021) in finding that scientific advances develop more slowly than their implementation in institutions and organizations. This leads to the possibilities of new lines of research, in particular focused on examining the ongoing use of automated systems within communication departments or political organizations and institutions. Although we find patchy research addressing this topic, many robotic posts may be employed systematically rather than only during key events. In other words, they not only relate to participation (the most abundant axis of those considered herein) but are also associated with other moments of civil participation.

Many features support the analysis above. The political polarization present in various countries such as Colombia, Ecuador, and Mexico means that a significant part of the population search for news that is close to their ideological convictions (Bendall; Robertson, 2018; Kim; Dennis, 2019) or emotions (McIntyre, 2019), in accordance with studies in other contexts. Moreover, some sources deliberately misinform (Illades, 2018) or disseminate promotional material in favor of particular organizational or institutional interests.

However, citizens do not remain static when faced with these phenomena. On the contrary, based on this literature review, we observe an increasing resistance to the influence of social networks, even in a context with gaps as noted in the current cases (Q2). An example of this is observed in Mexico, whose users are consuming less and less false news, either because the person who writes on Twitter is identified as an elite and, therefore, having high media literacy, or because the filters or self-regulation applied by Facebook are effective (Glowacki et al., 2018).

Obviously, in the studied countries, social networks have generated new possibilities for citizens by providing new tools for expressing, organizing, and carrying out collective action. However, in recent years, the need to evaluate the impact of these media on the quality of democracies has also been emphasized, which constitutes an emerging and necessary line of research (Piechota et al., 2020; De-la-Garza-Montemayor; Barredo-Ibáñez; López-López, 2021).

Likewise, we recommend that researchers review the involvement of artificial intelligence in other aspects of governance such as transparency, legitimacy, or human rights, with the purpose of providing an even more holistic overview of the use of this technology. Similarly, an extension of this exhaustive review to other countries in America, Europe, Asia, or Oceania is recommended, with the aim of providing a comparative vision and thereby achieving a global categorization of the use of artificial intelligence according to the type of regime and its level of democracy. The limitations of the present study are both contextual and temporal because of the progressively increasing access to technology in the countries analyzed and because their political and social situations may change over time.

\section{References}

Albán-Cabezas, Víctor-Daniel (2019). “Fake news, troles y bots: ¿a quiénes abraza la libertad de expresión?”. \#PerDebate, v. 3, n. 1, pp. 172-191.

https://doi.org/10.18272/pd.v3i1.1517

Alcivar, Nayeth I. S.; Houghton, Luke; Sanzogni, Louis (2017). “Understanding subjective aspects in the use of human computer interface for government information systems: a reflexive analysis". In: Proceedings of the 2017 international conference on computer science and artificial intelligence, pp. 24-31.

https://doi.org/10.1145/3168390.3168443 
Alcivar, Nayeth I. S.; Sanzogni, Louis; Houghton, Luke (2016). "Fuzzy QCA applicability for a refined selection of drivers affecting IS adoption: The case for Ecuador". In: 2016 IEEE Latin American conference on computational intelligence (LACCI).

https://doi.org/10.1109/LA-CCI.2016.7885695

Álvarez-Vega, Marianella; Quirós-Mora, Laura-María; Cortés-Badilla, Mónica-Valeria (2020). “Inteligencia artificial y aprendizaje automático en medicina". Revista médica sinergia, v. 5, n. 8, e557.

https://doi.org/10.31434/rms.v5i8.557

Applebaum, Anne (2020). Twilight of democracy. New York: Doubleday Books. ISBN: 9781984899507

Araujo-Alonso, Miguel (2011). “Fundamentos y limitaciones de la revisión de la literatura biomédica”. Medwave, v. 11, n. 10.

https://doi.org/10.5867/medwave.2011.10.5194

Arnau-Sabatés, Laura; Sala-Roca, Josefina (2020). La revisión de la literatura científica: pautas, procedimientos y criterios de calidad. Barcelona: Universitat Autònoma de Barcelona.

https://www.mdx.cat/handle/10503/69666

Baker, Andy; Ames, Barry; Rennó, Lúcio (2020). Persuasive peers: social communication and voting in Latin America. New Jersey: Princeton University Press. ISBN: 9780691205779

Bañuelos, Jacob (2017). “Fotografía móvil y redes sociales: prácticas de producción y socialización en jóvenes universitarios". Icono 14, v. 15, n. 1.

https://doi.org/10.7195/ri14.v15i1.999

Barredo-Ibáñez, Daniel (2021). Medios digitales, participación y opinión pública. Bogotá: Tirant Lo Blanch. ISBN: 97884 18329708

Barredo-Ibáñez, Daniel; Díaz-Cerveró, Elba (2017). “La interactividad en el periodismo digital latinoamericano. Un análisis de los principales cibermedios de Colombia, México y Ecuador (2016)”. Revista latina de comunicación social, n. 72 , pp. 273-294.

https://doi.org/10.4185/RLCS-2017-1165

Barrientos-Avendaño, Edwin; Coronel-Rojas, Luis-Anderson; Cuesta-Quintero, Fabián; Rico-Bautista, Dewar (2020). "Sistema de administración de ventas tienda a tienda: aplicando técnicas de inteligencia artificial". Revista ibérica de sistemas e tecnologías de informação, n. E27, pp. 677-689.

http://www.risti.xyz/issues/ristie27.pdf

Bendall, Mark; Robertson, Chris (2018). "The crisis of democratic culture?". International journal of media and cultural politics, v. 14, n. 3, pp. 383-391.

https://doi.org/10.1386/macp.14.3.383_7

BID (2020). La inteligencia artificial al servicio del bien social en América latina y el Caribe: panorámica regional e instantáneas de doce países. Washington: Banco Interamericano de Desarrollo.

https://doi.org/10.18235/0002393

Boas, Taylor C. (2020). "The electoral representation of evangelicals in latin America". Oxford research encyclopedia of politics. ISBN: 9780190933609

https://doi.org/10.1093/acrefore/9780190228637.013.1748

Bonow-Soares, Felipe (2020). "As estratégias de argumentação e as formas de desinformação nas mensagens de Jair Bolsonaro, no Twitter, durante o segundo turno das eleições presidenciais de 2018". Revista mediação, v. 22, n. 30, pp. 8-22.

http://revista.fumec.br/index.php/mediacao/article/view/7424

Bradshaw, Samantha; Howard, Philip N. (2017). Troops, trolls and troublemakers: a global inventory of organized social media manipulation. Oxford: University of Oxford.

https://demtech.oii.ox.ac.uk/wp-content/uploads/sites/89/2017/07/Troops-Trolls-and-Troublemakers.pdf

Braveboy-Wagner, Jacqueline-Anne (2009). Institutions of the Global South. London: Routledge. ISBN: 9780415365918 https://comprop.oii.ox.ac.uk/wp-content/uploads/sites/89/2017/07/Troops-Trolls-and-Troublemakers.pdf

Calderón, María-José (2019). "The use of social media and Al to shape democracy in Ecuador". In: Finlay, Alan. Global information society watch 2019. Artificial intelligence: Human rights, social justice and development. United States: Association for Progressive Communication, pp. 124-127. ISBN: 9789295113138

Campos-Domínguez, Eva; García-Orosa, Berta (2018). “Comunicación algorítmica en los partidos políticos: automatización de producción y circulación de mensajes". El profesional de la información, v. 27, n. 4, pp. 769-777.

https://doi.org/10.3145/epi.2018.jul.06 
Canavilhas, João; Colussi, Juliana; Moura, Zita-Bacelar (2019). “Desinformación en las elecciones presidenciales 2018 en Brasil: un análisis de los grupos familiares en WhatsApp". El profesional de la información, v. 28, n. 5, e280503. https://doi.org/10.3145/epi.2019.sep.03

Castellanos-Claramunt, Jorge (2019). “La democracia algorítmica: inteligencia artificial, democracia y participación política". Revista general de derecho administrativo, n. 50.

https://www.iustel.com/v2/revistas/detalle_revista.asp?id_noticia $=421171 \& d=1$

Castells, Manuel (2012). Redes de indignación y esperanza: los movimientos sociales en la era de internet. Madrid: Alianza Editorial. ISBN: 9788420609607

Cerón-Guzmán, Jhon-Adrián; León-Guzmán, Elizabeth (2015). “Detecting social spammers in Colombia 2014 presidential election". Lecture notes in computer science, v. 9414, pp. 121-141.

https://doi.org/10.1007/978-3-319-27101-9_9

Cerón-Guzmán, Jhon-Adrián; León-Guzmán, Elizabeth (2016). “A sentiment analysis system of Spanish tweets and its application in Colombia 2014 presidential election". In: 2016 IEEE International conferences on big data and cloud computing (BDCloud), Social computing and networking (SocialCom), Sustainable computing and communications (SustainCom) (BDCloud-SocialCom-SustainCom), October, pp. 250-257.

https://doi.org/10.1109/BDCloud-SocialCom-SustainCom.2016.47

Cha, Meeyoung; Gao, Wei; Li, Cheng-Te (2020). "Detecting fake news in social media: an Asia-Pacific perspective". Communications of the ACM, v. 63, n. 4, pp. 68-71.

https://doi.org/10.1145/3378422

Chen, Xiaotian (2018). "Calling out fake news on social media: a comparison of literature in librarianship and journalism". Internet reference services quarterly, v. 23, n. 1-2.

https://doi.org/10.1080/10875301.2018.1518284

Chenou, Jean-Marie; Cabarcas-Velandia, Daniel; Sepúlveda-Marín, María-Nicoll (2021). "Social media and political polarization in Latin America. Analyzing online discussions during the 2018 presidential campaign in Colombia". In: Ramírez-Plascencia, David; Carvalho-Gurgel, Barbara; Plaw, Avery. The politics of technology in Latin America. New York: Routledge, pp. 129-146. ISBN: 9780429343247

https://doi.org/10.4324/9780429343247

Clark, Eric M.; Williams, Jake-Ryland; Jones, Chris A.; Galbraith, Richard A.; Danforth, Christopher M.; Dodds, Peter-Sheridan (2016). "Sifting robotic from organic text: A natural language approach for detecting automation on Twitter". Journal of computational science, n. 16.

https://doi.org/10.1016/j.jocs.2015.11.002

Clarke, John; Newman, Janet (2017). "What's the subject? Brexit and politics as articulation”. Journal of community \& applied social psychology, v. 29, n. 1, pp. 67-77.

https://doi.org/10.1002/casp.2376

Codina, Lluís (2018). "Revisiones sistematizadas para trabajos académicos 1: Conceptos, fases y bibliografía". Blog Lluís Codina, 11 abril.

https://www.lluiscodina.com/revisiones-sistematizadas-fundamentos

Cumbicus-Pineda, Óscar-Miguel (2017). Categorización automática de tweets sobre el tema político electoral aplicando algoritmos de clasificación supervisada. Leioa: Universidad del País Vasco.

http://hdl.handle.net/10810/22632

Davies, William (2019). Nervous states: democracy and the decline of reason. New York: W. W. Norton \& Company. ISBN: 9780393357943

De-la-Garza-Montemayor, Daniel-Javier; Barredo-Ibáñez, Daniel; López-López, Paulo-Carlos (2021). “Crisis of democracy, social media and the digital age: The narrative of specialists from Spain, Mexico and Peru". In: Rocha, Álvaro; Ferrás, Carlos; López-López, Paulo-Carlos; Guarda, Teresa. ICITS 2021. Information technology and systems. Advances in intelligent systems and computing. Switzerland: Springer, v. 1331, pp. 169-178.

https://doi.org/10.1007/978-3-030-68418-1_18

De-la-Garza-Montemayor, Daniel-Javier; La-Rosa-Pinedo, Amaro; Barredo-Ibáñez, Daniel; Freundt-Thurne, Úrsula (2019). "Medios sociales, capital social y sentimiento de eficacia política: Un estudio comparativo entre las juventudes de México y Perú". En: Badillo-Mendoza, Miguel-Ezequiel; Pérez-Lagos, Camila; Medranda-Morales, Narcisa-Jessenia; Cortés-Cortés, María-Isabel (eds.). Ciudadanías digitales. Perspectivas desde los medios, el periodismo y la educomunicación. Bogotá: Politécnico Grancolombiano, pp. 133-154. ISBN: 9789585544314

https://dialnet.unirioja.es/servlet/articulo?codigo $=7776895$ 
De-la-Garza-Montemayor, Daniel-Javier; Yllán-Ramírez, Elisa-Raquel (2020). “Efectos de la ciberpolítica en la democracia contemporánea: percepciones de profesores universitarios en México y España”. RISTI, v. 26, n. 2, pp. 40-54. https://search.proquest.com/openview/4155b9209816029cc8473e1ecdca8cc0/1?pq-origsite=gscholar \&cb/=1006393

Denneen, Patrick J. (2018). Why liberalism failed. New Haven, CT: Yale University Press. ISBN: 9780300223446

Domínguez-Ávila, Carlos-Federico; Vásquez-Von-Schoettler, Werner; Rezende-da-Silva, Alessandro (2019). “Democracia digital, ciudadanía y soberanía en las redes sociales virtuales: una aproximación teórica al estado de situación digital en América latina". Revista Neiba. Cadernos Argentina Brasil, v. 8, n. 1.

https://doi.org/10.12957/neiba.2019.42784

Eichengreen, Barry (2018). The populist temptation: economic grievance and political reaction in the modern era. Oxford: Oxford University Press. ISBN: 9780190866280

Fabra-Mata, Javier; Mygind, Jesper (2018). "Big data in evaluation: Experiences from using Twitter analysis to evaluate Norway's contribution to the peace process in Colombia". Evaluation, v. 25, n. 1, pp. 6-22.

https://doi.org/10.1177/1356389018804259

Fernández-de-Arroyabe-Olaortua, Ainhoa; Lazkano-Arrillaga, Iñaki; Eguskiza-Sesumaga, Leyre (2018). “Digital natives: Online audiovisual content consumption, creation and dissemination". Comunicar, n. 57, pp. 61-69.

https://doi.org/10.3916/C57-2018-06

Ferrara, Emilio; Varol, Onur; Davis, Clayton; Menczer, Filippo; Flammini, Alessandro (2016). "The rise of social bots". Communications of the ACM, v. 59, n. 7, pp. 96-104.

https://doi.org/10.1145/2818717

Galston, William A. (2018). Anti-pluralism: the populist threat to liberal democracy. Michigan: Yale University Press. ISBN: 9780300235319

https://doi.org/10.2307/j.ctt21668rd

Gater, William (2019). "Populism, the media, and fake news". Japan mission journal, v. 73, n. 3, pp. 188-195.

Glowacki, Monika; Narayanan, Vidya; Maynard, Sam; Hirsch, Gustavo; Kollanyi, Bence; Neudert, Lisa-Maria; Howard, Phil; Lederer, Thomas; Barash, Vlad (2018). News and political information consumption in Mexico: mapping the 2018 Mexican presidential election on Twitter and Facebook. Data memo 2018.2. Oxford, UK: Project on Computational Propaganda.

https://demtech.oii.ox.ac.uk/research/posts/news-and-political-information-consumption-in-mexico-mapping-the2018-mexican-presidential-election-on-twitter-and-facebook

Gómez-Mont, Constanza; Del-Pozo, Claudia-May; Martínez-Pinto, Cristina; Martín-del-Campo-Alcocer, Ana-Victoria (2020). La inteligencia artificial al servicio del bien social en América Latina y el Caribe: panorámica regional e instantáneas de doce países. Banco Interamericano de Desarrollo.

https://publications.iadb.org/publications/spanish/document/La-inteligencia-artificial-al-servicio-del-bien-social-en-America-Latina-y-el-Caribe-Panor\%C3\%A1mica-regional-e-instant\%C3\%A1neas-de-doce-paises.pdf

Guerrero-Solé, Frederic; Suárez-Gonzalo, Sara; Rovira, Cristòfol; Codina, Lluís (2020). "Social media, context collapse and the future of data-driven populism". Profesional de la información, v. 29, n. 5, e290506.

https://doi.org/10.3145/epi.2020.sep.06

Guillén-Zanón, Ángel (1990). “La técnica del grupo nominal”. Documentación administrativa, n. 223, pp. 51-98. https://doi.org/10.24965/da.v0i223.5196

Gutiérrez-Atala, Fernando; Domínguez-Panamá, Juan; Odriozola-Chené, Javier; Ferreira-Jiménez, Javier (2017). “Limitantes formativas en la praxis profesional: estudio de la situación de periodistas en Chile, México, Ecuador y Colombia”. Comuni@cción: revista de investigación en comunicación y desarrollo, v. 8, n. 1, pp. 37-47.

https://www.comunicacionunap.com/index.php/rev/article/view/151

Hall, Wendy; Tinati, Ramine; Jennings, Will (2018). "From Brexit to Trump: social media's role in democracy". Computer, v. 51, n. 1 , pp. $18-27$.

https://doi.org/10.1109/MC.2018.1151005

Hart, Chris (2018). Doing a literature review: Releasing the social science research imagination. London: Sage. ISBN: 978 0761959755

Heawood, Jonathan (2018). "Pseudo-public political speech: Democratic implications of the Cambridge Analytica scandal". Information polity, v. 23, n. 4, pp. 429-434.

https://doi.org/10.3233/IP-180009

Helbing, Dirk; Frey, Bruno S.; Gigerenzer, Gerd; Hafen, Ernest; Hagner, Michael; Hofstetter, Yvonne; Van-den-Hoven, Jeroen; Zicari, Robeto V.; Zwitter, Andrej (2019). "Will democracy survive big data and artificial intelligence?". In: Helbing, Dirk. Towards digital enlightenment. Cham: Springer, pp. 73-98. 
Hernández-Sampieri, Roberto; Fernández-Collado, Carlos; Baptista-Lucio, Pilar (2010). Metodología de la investigación. México DF: McGraw Hill. ISBN: 9786071502919

Hobden, Christine (2018). "Unequal political engagement and the possible risks to democracy". Theoria, v. 65 , n. 3. https://doi.org/10.3167/th.2018.6515601

Illades, Esteban (2018). Fake news, la nueva realidad. Ciudad de México: Grijalbo. ISBN: 9786073160889

Innerarity, Daniel (2020). "El impacto de la inteligencia artificial en la democracia". Revista de las Cortes Generales, n. 109, pp. 87-103.

https://doi.org/10.33426/rcg/2020/109/1526

Judis, John B. (2016). The Populist explosion: how the Great Recession transformed American and European politics. New York: Columbia Global Reports. ISBN: 9780997126440

Kaiser, Brittany (2019). Targeted: the Cambridge Analytica whistleblower's inside story of how big data, Trump, and Facebook broke democracy and how it can happen again. New York: Harper. ISBN: 9780062965790

Kim, Antino; Dennis, Alan R. (2019). "Says who? The effects of presentation format and source rating on fake news in social media". MIS quarterly, v. 43, n. 3, pp. 1025-1039.

https://doi.org/10.25300/MISQ/2019/15188

Landman, Todd; Beetham, David; Carvalho, Edzia; Weir, Stuart (2009). Evaluar la calidad de la democracia. Estocolmo: Instituto Internacional para la Democracia y la Asistencia Electoral. ISBN: 9789185724659

https://www.idea.int/sites/default/files/publications/chapters/evaluar-la-calidad-de-la-democracia/evaluar-la-calidadde-la-democracia-una-introduccion.pdf

Lipiński, Artur; Stępińska, Agnieszka (2019). "Polish right-wing Populism in the era of social media". Problems of post-communism, v. 66, n. 1, pp. 71-82.

https://doi.org/10.1080/10758216.2018.1484667

López-López, Paulo-Carlos; Oñate, Pablo (2019). “De la videopolítica a la ciberpolítica: debate entre candidatos y televisiones en cinco elecciones presidenciales". El profesional de la información, v. 28, n. 5, e280512

https://doi.org/10.3145/epi.2019.sep.12

Lupu, Noam; Ramírez-Bustamante, Mariana V.; Zechmeister, Elizabeth J. (2020). "Social media disruption: messaging mistrust in Latin America". Journal of democracy, v. 31, n. 3, pp. 160-171

https://muse.jhu.edu/article/760080/summary

Luque, Arturo; Macías, Julián; Casado, Fernando (2021). La democracia de los trolls y el asalto a la democracia. Análisis del proceso electoral en Ecuador y los elementos irradiadores que lo conforman a través de sus redes sociales. Manabí: Ediciones UTM. ISBN: 9789942389053

Mancosu, Moreno; Bobba, Giuliano (2019). “Using deep-learning algorithms to derive basic characteristics of social media users: The Brexit campaign as a case study". Plos one, v. 14, n. 1, e0211013.

https://doi.org/10.1371/journal.pone.0211013

Marantz, Andrew (2019). Antisocial: online extremists, techno-Utopians, and the hijacking of the American conversation. New York: Viking. ISBN: 9780525522263

McIntyre, Lee (2019). Post-truth. Cambridge: MIT Press. ISBN: 9780262535045

Méndez-Zapata, Tatiana; Quintuña-Barbecho, Freddy; Robles-Bykbaev, Vladimir; Ingavélez-Guerra, Paola (2015). “Estimulación de sensopercepciones: un enfoque educativo basado en inteligencia artificial". Revista tecnológica Espol, v. 28, n. 4, pp. 28-39.

http://www.rte.espol.edu.ec/index.php/tecnologica/article/view/398

Mladenova, Tsvetelina; Kalmukov, Yordan; Valova, Irena (2020). “Covid 19 - A major cause of digital transformation in education or just an evaluation test". TEM journal, v. 9, n. 3, pp. 1163-1170.

https://doi.org/10.18421/TEM93-42

Montenegro-López, Diego (2020). “Uso de tecnologías en el lugar de atención para el manejo de la pandemia por Covid-19 en Colombia". Pan American journal of public health, v. 44.

https://doi.org/10.26633/RPSP.2020.97

Morgus, Robert; Fonseca, Brian; Green, Kieran; Crowther, Alexander (2019). "Are China and Russia on the cyber offensive in Latin America and the Caribbean? a review of their cyber capabilities and implications for the U.S. and its partners in the region". New America, n. 26, pp. 1-50.

https://www.newamerica.org/cybersecurity-initiative/reports/russia-china-cyber-offensive-latam-caribbean 
Muthiah, Sathappan; Huang, Bert; Arredondo, Jaime; Mares, David; Getoor, Lise; Katz, Graham; Ramakrishnan, Naren (2016). "Capturing planned protests from open source indicators". Al magazine, v. 37, n. 2, pp. 63-75. https://doi.org/10.1609/aimag.v37i2.2631

Nemitz, Paul (2018). "Constitutional democracy and technology in the age of artificial intelligence". Philosophical transactions of the Royal Society A: Mathematical, physical and engineering sciences, v. 376, n. 2133, 20180089. https://doi.org/10.1098/rsta.2018.0089

O’Donnell, Guillermo; Vargas-Cullell, Jorge; Lazzetta, Oswaldo M. (2004). The quality of democracy: theory and applications. Notre Dame: The university of Notre Dame Press. ISBN: 9780268160685 https://doi.org/10.2307/j.ctvpj74f5

Patiño, Carlos A. (2021). "La policía predictiva como estrategia de inteligencia para la disuasión de eventos delictivos". En: Inteligencia artificial y ética en la gestión pública. Caracas: Centro Latinoamericano de Administración para el Desarrollo, pp. 209-217. ISBN: 9789807925143

https://clad.org/wp-content/uploads/2021/03/Libro-7-Inteligencia-artificial-y-\%C3\%A9tica-en-la-gesti\%C3\%B3np\%C3\%BAblica.pdf

Pérez-Casares, Alexandre (2018). "The brain of the future and the viability of democratic governance: The role of artificial intelligence, cognitive machines, and viable systems". Futures, v. 103, pp. 5-16.

https://doi.org/10.1016/j.futures.2018.05.002

Piechota, Grażyna; Rajczyk, Robert; Lytvynenko, Volodymir; Grydchyna, Viktoriia (2020). "The type of participation in socio-political protests as a function of political activation in the era of social media". Romanian journal of political science, v. 20, n. 1, pp. 188-213.

http://www.sar.org.ro/polsci/?p=1416

Pizarroso-Quintero, Alejandro (1999). "La historia de la propaganda: una aproximación metodológica". Historia y comunicación social, n. 4, pp. 145-171.

https://revistas.ucm.es/index.php/HICS/article/view/HICS9999110145A/19646

Proaño-Salazar, César-Paúl (2021). “Banderas rojas: algoritmos anticorrupción para transparentar la contratación pública en el Ecuador". En: Inteligencia artificial y ética en la gestión pública. Caracas: Centro Latinoamericano de Administración para el Desarrollo, pp. 201-208. ISBN: 9789807925143

https://clad.org/wp-content/uploads/2021/03/Libro-7-Inteligencia-artificial-y-\%C3\%A9tica-en-la-gesti\%C3\%B3n-p\%C3\%BAblica.pdf

Puyosa, Iria (2017). "Bots políticos en Twitter en la campaña presidencial\# Ecuador 2017”. Contratexto, n. 27, pp. 39-60. https://doi.org/10.26439/contratexto.2017.027.002

Rigg, Jonathan (2007). An everyday geography of the Global South. London: Routledge. ISBN: 9780203967577 https://doi.org/10.4324/9780203967577

Roa-Roa, Jorge-Ernesto (2019). “Redes sociales, justicia constitucional y deliberación pública de calidad: lecciones del plebiscito por la paz en Colombia”. Revista brasileira de políticas públicas, v. 9, n. 2, pp. 203-217.

https://doi.org/10.5102/rbpp.v9i2.6209

Rodríguez-Pérez, Carlos (2020). "Una reflexión sobre la epistemología del fact-checking journalism: retos y dilemas". Revista de comunicación, v. 19, n. 1, pp. 243-258.

https://doi.org/10.26441/RC19.1-2020-A14

Rodríguez-Pérez, Carlos; Ortiz-Calderón, Laura-Sofía; Esquivel-Coronado, Juan-Pablo (2021). “Desinformación en contextos de polarización social: el paro nacional en Colombia del 21N". Anagramas rumbos y sentidos de la comunicación, v. 19, n. 38, pp. 129-156.

https://doi.org/10.22395/angr.v19n38a7

Rúas Araújo, Xosé; Casero-Ripollés, Andreu (2018). “Comunicación política en la época de las redes sociales: lo viejo y lo nuevo, y más allá". AdComunica, n. 16, pp. 21-24.

https://doi.org/10.6035/2174-0992.2018.16.2

Ruvalcaba-Gómez, Edgar A. (2021). “Inteligencia artificial en los gobiernos locales de México: análisis de percepciones de los responsables de las TIC". En: Inteligencia artificial y ética en la gestión pública. Caracas: Centro Latinoamericano de Administración para el Desarrollo, pp. 111-138. ISBN: 9789807925143

https://clad.org/wp-content/uploads/2021/03/Libro-7-Inteligencia-artificial-y-\%C3\%A9tica-en-la-gesti\%C3\%B3np\%C3\%BAblica.pdf

Sancho, Rosa (1990). "Indicadores bibliométricos utilizados en la evaluación de la ciencia y la tecnología. Revisión bibliográfica”. Revista española de documentación científica, v. 13, n. 3-4, pp. 77-106.

https://doi.org/10.3989/redc.1990.v13.i3.842 
Sierra-Caballero, Francisco; Sola-Morales, Salomé (2020). "Golpes mediáticos y desinformación en la era digital. La guerra irregular en América Latina". Comunicación y sociedad, v. 17, e7604.

https://doi.org/10.32870/cys.v2020.7604

Simpson, Patricia-Anne (2016). "Mobilizing meanings: translocal identities of the far right web". German politics and society, v. 34, n. 4, pp. 34-53.

https://doi.org/10.3167/gps.2016.340403

Singer, Peter-Warren; Brooking, Emerson T. (2018). LikeWar: the weaponization of social media. Boston: Houghton Mifflin Harcourt. ISBN: 9781328695741

Swigger, Nathaniel (2013). "The online citizen: is social media changing citizens' beliefs about democratic values?". Political behavior, n. 35, pp. 589-603.

https://doi.org/10.1007/s11109-012-9208-y

Tana, Jonas; Eirola, Emil; Nylund, Mats (2020). "When is prime-time in streaming media platforms and video-on-demands services? New media consumption patterns and real-time economy". European journal of communication, v. 35, n. 2, pp. 108-125.

https://doi.org/10.1177/0267323119894482

Tapia, Patricia; Mackliff, Verónica; Mora, Alexandra; Renteria, Fanny (2021). "Tecnologías de la información y comunicación aplicadas en la educación inclusiva del Ecuador". Revista Clake education, v. 2, n. 1.

http://revistaclakeeducation.com/ojs/index.php/Multidisciplinaria/article/view/71

Thomas-Slayter, Barbara P. (2003). Southern exposure: international development and the Global South in the twenty-first century. Bloomfield, USA: Kumarian Press. ISBN: 9781565491748

Timoteo, Jesús (2005). Gestión del poder diluido. La construcción de la sociedad mediática (1989 - 2004). Madrid: Pearson Educación. ISBN: 8420542318

Toapanta-Toapanta, Segundo-Moisés; Orellana-Vélez, Nathaly-Vanessa; Barona-Valencia, Danny-Wilfrido; Mafla-GaIlegos, Luis-Enrique (2019). "Analysis cryptographic for electronic votes in systems of distributed architectures". In: 2019 International conference on artificial intelligence and advanced manufacturing (AIAM), pp. 44-49.

https://doi.org/10.1109/AIAM48774.2019.00016

Torres, Johnny; Baquerizo, Gabriela; Vaca, Carmen (2015). “Caracterización de líderes políticos de Ecuador en Twitter usando aprendizaje de máquina no supervisado". Revista tecnológica Espol, v. 28, n. 5, pp. 520-533.

http://www.rte.espol.edu.ec/index.php/tecnologica/article/view/458

Toxtle-Tlachino, Alejandra; González-Macías, Rubén-Arnoldo (2020). “Facebook, una extensión de marketing y no un espacio deliberativo: caso de Andrés Manuel López Obrador en elecciones presidenciales de México en 2018". Global media journal México, v. 17, n. 33, pp. 72-95.

https://doi.org/10.29105/gmjmx17.33-4

Von-Foerster, Heinz (1991). Las semillas de la cibernética. Barcelona: Gedisa. ISBN: 9788474324143

Walters, Ryan M. (2018). "How to tell a fake: fighting back against fake news on the front lines of social media". Texas review of law \& politics, v. 23, n. 1, pp. 111-179.

https://rl.talis.com/3/lsbu/items/C5C44F8D-9007-1320-39E2-39E1E7386E61.html

Weaver, Russell L. (2020). Social media platforms and democratic discourse. Symposium, v. 23, n. 4, pp. $1385-1416$. https://law./clark.edu/live/files/29480-Icb234art6weaverpdfpdf

Wiener, Norbert (1949). Cybernetics or control and communication in the animal and the machine. New York: The Technology Press. ISBN: 9780262537841

Xiao, Yu; Watson, Maria (2019). “Guidance on conducting a systematic literature review". Journal of planning education and research, v. 39, n. 1, pp. 93-112.

https://doi.org/10.1177/0739456X17723971

Yerby, Johnathan; Koohang, Alex; Paliszkiewicz, Joanna (2019). "Social media privacy concerns and risk beliefs". The online journal of applied knowledge management, v. 7, n. 1.

https://doi.org/10.36965/OJAKM.2019.7(1)1-13

Yerlikaya, Turgay; Toker-Aslan, Seca (2020). "Social media and fake news in the post-truth era: the manipulation of politics in the election process". Insight Turkey, v. 22, n. 2, pp. 177-196.

https://doi.org/10.25253/99.2020222.11 